\title{
STRUCTURAL FEATURES FOR COGNITIVE REPRESENTATIONS OF TRAUMATIC EMOTIONAL EXPERIENCE AMONG DEMOBILIZED COMBATANTS IN UKRAINE WITH POST-STRESS PSYCHOLOGICAL DISADAPTATION
}

\author{
Andriy O. Kharchenko \\ Факультет психології, Харківський наџіональний університет ім. В.Н. Каразіна, \\ Харків, 61077, Украӥна. \\ E-mail: kharchenkoao091284@gmail.com,http://orcid.org/0000-0001-6685-1498
}

\begin{abstract}
Problem definition In the scientific literature, there is a certain polyparametric nature of approaches to treating PPD (post-stress psychological desadaptation) in military personnel, which adds to the difficulty of dealing with their complaints and is complicated by resistance to therapeutic work with PPD. Also described (Yermoshin AF, Kocharian AS) some features of traumatic experience of personality, namely traumatic experiences: their somatization, fragmentation, cyclicity, etc. The cognitive component of traumatic experience, which is manifested in PTSD in military personnel, remains insufficiently disclosed. Problem analysis The results of both theoretical and practical studies that have attempted to determine the features of cognitive representations of traumatic experiences of military personnel are fragmentary in nature. The concept of "emotional sphere" proposed by Elliott R. and Greenberg L. includes the cognitive component, as one of the basic parts of traumatic personality experience, which can be used to conceptualize in the study of the traumatic experience of servicemen. The purpose of the study To determine structural features of cognitive representations of traumatic experience in Soldiers with PPD. Description of the sample The sample consists of two groups. The first group included middleaged men who had served in the ATO area and were demobilized in the amount of 100 people. The second group is identical in terms of the above characteristics, but these are those servicemen who have Mississippi scale scores that correspond to the severity of the PDD. Conclusions: Demobilized PPD combatants exhibited a pronounced expression of all cognitive representations of traumatic experiences that are substantially closer to the themes of abandonment, humiliation, and injustice, at a significantly higher level than those demobilized without PPD. expressiveness of cognitive representations on the topics of trauma of abandonment, humiliation and injustice in the interaction of which revealed the phenomenon of "wrecking", do not contribute to the occurrence of PPD, unless potentiated by appropriate infantile traumatization.
\end{abstract}

KEY WORDS: military personnel, post-stress, traumatic experience, structure, cognitive representations.

Problem statement: ATO participation leads to a deterioration of the mental and psychological health among military. According to the Prosecutor General of Ukraine (Anatoly Matios), there are suicides (518 cases), aggressive attitude often associated with alcohol consumption and other addictive behaviours $(15 \%$ of crimes related to servicemen are due to alcohol or drug use, and every sixth non-military loss is associated with drinking), problems with re-socialization and readaptation. One of the key issues remains the reduction of symptoms for post-stress psychological disadaptation (PTSD), which are often resistant to therapy.

Existing approaches to the conceptualization of the mechanisms and factors behind the formation of PTSD reflect medical and psychological aspects. The cognitive sphere is seen as the one which suffers from stress. There are various manifestations of cognitive impairment. Meanwhile, the cognitive sphere as such, which participates in the pathogenetic mechanisms of PTSD and in its donozological variant - post-stress psychological disadaptation - is generally not considered enough. However, in emotionally focused therapy the affection becomes central to the understanding of psychogenesis.

Problem analysis: In science, the issue of military traumatic experience is defined as PTSD, which has undergone serious analysis, including by domestic authors: Shestopalova L.F., Markova M.V., Podkorytov V.S., Maruta N.O., Rachkauskas G.S., Bolotov D.M., Belov V.G. and others. The main criteria that characterize PTSD are: 1) the stress state experienced, 2) the influx of memories about the place where life threatening situations took place, the emergence of "guilt for surviving" before the victims, dreaming with nightmarish scenes of the experience, 3 ) the desire to avoid emotional strain, fear of distressing memories, non-contact with others, 4) a complex of neurasthenic disorders mainly with increased irritability, decreased concentration, attention, "tonus of functioning", 5) stigma of certain patho-characteristic symptoms

(C) Andriy O. Kharchenko, 2019 
and tendencies in the formation of psychopathic tendencies with antisocial behavior episodes (alcoholism, drug abuse, cynicism, lack of respect for officials). Smirnova L.V., analyzing the predictors of PTSD, points to their great variation: psychiatric injuries at an early age, hereditary load of mental illness, and factors of retraumatization, as indicated by S. Robert (Kocharyan, 2014; Kozyra, 2016; Kozyra, 2016; Kharchenko, 2017; Методичні рекомендації, 2014; Kokun, 2016; Workshop, 2001; Tarabrina, 2007; Lauterbach, 1995). There are data regarding personality traits as predisposing factors for PTSD: V.M. Litkin points to emotional instability and certain personality traits, V.D. Vid and E.M. Yepachintsev talks about emotional instability and increased anxiety, M.A. Jishkariani emphasizes the importance in the influence of asthenic traits, there are ideas of PTSD on the "basis" of mental illness and the dominance in one of the basic emotions, as a predictor of PTSD - the main component of this experience and idea of its intensification or attenuation, etc. However, the military has a certain number of disorders on the preclinical level, one of which includes post-stress psychological disadaptation, which is understudied in psychology, although as Safin O.D. notes, it is manifested in a much larger number of military than PTSD. Hereinafter, we will refer to the term "poststress psychological disadaptation" (PPD), which was introduced and substantiated in the work of P.P. Trump. At the same time, the scientist notes that "disadaptation of the psychological level is most fully characterized by the general deviant syndrome of personal adaptation", not specific and polymorphic manifestations of which represent this donozological level of response to a stressful situation. Analyzing this issue, Kozira P.V. points to the work of such scientists as Zagurovsky V.M., Bulan A.A., Alexandrovskiy Yu. A., Gurevich P.S., who emphasize the dependence of the specific response to the stress among military on the character, personality, duration and intensity of stress factors, maturity and adequacy of protective mechanisms (Kozyra, 2016; Kozyra, 2016; Kharchenko, 2017). From our point of view, it is a constructive idea of the emotional scheme, which is developed within the concept of proceduralexperimental psychotherapy (PEP) by L. Greenberg, R. Elliott (Kharchenko, 2017; Методичні рекомендаціï, 2014). Cognitions, as part of this scheme, in some way determine and connect motivation, cognitive realm, memory system and bodily manifestations. Given the importance of cognitive representations in the emotional experience for the individual in the fullness of psychological health, which is shown in the works performed under the guidance of A.S. Kocharian and co-authors, it is necessary to fill this field with the results of researches that create a unified concept of structure for traumatic emotional experience among demobilized (Kocharyan, 2014; Workshop, 2001; Lauterbach, 1995).

The purpose of the study is to determine the structural features for cognitive representations of infantile traumatic experience among demobilized combatants in Ukraine with post-stress psychological disadaptation.

Sample description The study was conducted on the basis of Kharkiv Regional Organization for ATO Veterans. Two groups were formed with a total number of 200 people. The first group included 100 demobilized combatants with post-stress psychological disadaptation (group 1). Post-stress psychological disadaptation is a subclinical manifestation of disadaptation, which we diagnosed on the Mississippi scale for evaluating posttraumatic reactions (military option) as a sign of PTSD. The demobilized were not treated in the hospital and were not diagnosed with PTSD. Psychological signs were as follows: anxiety, irritability, mood swings, aggression, fear, sleep disturbance, decreased and mood swings, change of attitude to oneself and others. The second group included 100 middle-aged men without post-stress psychological disadaptation who were demobilized combatants (group 2).

\section{Results of research and their validation.}

Beck A., Ellis A., McMullin R. note that the existence of nonadaptive structures for cognitive sphere is a major cause of disturbance in "psychological homeostasis" (A. Beck's term). Nonadaptive cognitions are organized around rooted beliefs, which are the basic cognitive formations, as a consequence of traumatic personality. They cause most of the destructive behavioral patterns to emerge (Tarabrina, 2007).

In the concept of emotional scheme, the qualitative features of the cognitive component are interrelated with its other components, but have their specific place in the functioning of the traumatic experience. Based on Burbo L.'s theoretical foundations (characteristics of infantile trauma), we 
have formulated fifteen cognitive representations of traumatic experience (five for each trauma, respectively) to diagnose the cognitive equivalent of traumatic experience (Lauterbach, 1995). Since the difference in the severity of injuries between Gr. 1 and Gr. 2 was found to be "abandonment", "humiliation" and "injustice" (see Table 3.1), and it was appropriate to formulate cognitive representations of traumatic experiences that are characteristic only for these types of infantile traumas. Subsequently, an expert evaluation of these representations was carried out. Experts were selected by the specialists of the faculty of psychology in Kharkiv National University named after V. N. Karazin and psychology department of the National Aerospace University named after M.E. Zhukovsky "KhAI". The expert evaluation was carried out in two stages. First, the experts made their comments on the correctness and accuracy of representation shape. Following the information collected, they were adjusted and re-offered to experts for evaluation. The degree of meaningful validity for each cognitive representation in traumatic experience was evaluated on a five-point Likert-type scale. Subsequently, those cognitive representations of traumatic experience (three for each of the traumas) were left, resulting in high total scores and significant coefficients for internal consistency of experts. The data are shown in Table 1.

Table 1.

Internal consistency indicators among experts in cognitive representations of traumatic experience

\begin{tabular}{|l|l|c|}
\hline \multicolumn{1}{|c|}{ Trauma } & \multicolumn{1}{|c|}{ Cognitive representation } & W \\
\hline Abandonment & $\begin{array}{l}\text { Occasionally there appear thoughts that I was left alone with my } \\
\text { problems. }\end{array}$ & $0,77^{*}$ \\
\cline { 2 - 3 } & I occasionally get the idea that I can do little myself. & $0,74^{*}$ \\
\cline { 2 - 3 } & $\begin{array}{l}\text { To be successful, you need to listen maximum suggestions from } \\
\text { others. }\end{array}$ & $0,65^{*}$ \\
\hline Humiliation & I believe that certain conditions of my life are humiliating. & $0,81^{*}$ \\
\cline { 2 - 3 } & Sometimes I disagree with that, but others say I take too much work & $0,67^{*}$ \\
\cline { 2 - 3 } & $\begin{array}{l}\text { If there is a difficult life situation in dealing with people that are } \\
\text { important to me (for example: conflict, quarrel), to resolve it } \\
\text { sooner, it is better to act as a man and accept the blame for the } \\
\text { situation. }\end{array}$ & $0,73^{*}$ \\
\hline Injustice & I think they often act unfairly to me. & $0,69^{*}$ \\
\cline { 2 - 3 } & I believe that everything must be always striving for perfection. & $0,76^{*}$ \\
\cline { 2 - 3 } & $\begin{array}{l}\text { If a person close to me works and I am resting at this time, I find } \\
\text { injustice and my unforgivable guilt. }\end{array}$ & $0,68^{*}$ \\
\hline
\end{tabular}

Note: $\mathrm{W}-$ the Kendall coefficient of concordance; * $-\mathrm{p} \leq 0,05$.

Demobilized received a Likert-type rating scale: 1) strongly disagree; 2) disagree; 3 ) neither agree nor disagree; 4) agree; 5) strongly agree.

When processing the results of the survey, points were scored from 1 to 5 in accordance with the variants of the answers, that is, 1 point - when answering "strongly disagree" and 5 points - when answering "strongly agree". Subsequently, the scores on the three representations of each trauma for each subject were summed up. The significance of the difference in the total scores for each of the injuries between demobilized with and without PPD is presented in Table 2.
Demobilized combatants with PPD show an expression of all cognitive representations in traumatic experiences that are substantially closer to the topics of abandonment, humiliation and injustice, at a significantly higher level than those demobilized without PPD. Therefore, current traumatic experiences reflect relevant childhood traumas that are filled with new meaningful content but generally correspond to infantile traumas.

The structure for cognitive representations of traumatic experience by the above types of traumas in Gr. 1 and Gr. 2 is given in Table 3. 
Difference of expressiveness in cognitive representations with traumatic subjects by Burbo L. between Gr. 1 та 2

\begin{tabular}{|c|c|c|c|}
\hline \multirow{2}{*}{ Designation of representations } & \multicolumn{2}{|c|}{ Xmiddle } & \multirow{2}{*}{ U } \\
\cline { 2 - 3 } & Gr. 1 & Gr. 2 & 1394* \\
\hline Abandonment & 7,13 & 5,28 & $1011^{* *}$ \\
\hline Humiliation & 7,25 & 3,65 & $993^{* *}$ \\
\hline Injustice & 8,22 & 4,74 & \multirow{2}{*}{} \\
\hline
\end{tabular}

Note: Xmiddle is the mean score of traumatic cognitive expressions; $U$ - Mann-Whitney criterium; * - $\mathrm{p} \leq 0,05$; $* *$ - $\mathrm{p} \leq 0,01$.

Table 3 .

Structural features for cognitive representations of traumatic experience among demobilized Gr. 1 and Gr. 2

\begin{tabular}{|c|c|c|c|}
\hline Representations by traumas & Abandonment & Humiliation & Injustice \\
\hline Abandonment & $1,00^{* *}$ & $0,21^{* *}$ & $0,20^{* *}$ \\
\hline Humiliation & 0,02 & $1,00^{* *}$ & $0,18^{*}$ \\
\hline Injustice & 0,05 & $0,16^{*}$ & $1,00^{* *}$ \\
\hline
\end{tabular}

Note: top of the table - results for Gr. 1 ; bottom of the table - results for Gr. $2 ;^{*}-p \leq 0,05 ;{ }^{*}$ - $p \leq 0,01$.

The differences between the structures for cognitive representations of traumatic experience among demobilized combatants with and without PPD were identified (see Table 3.). In the case of demobilized PPDs, these features consist of "sticking together" and potentiating representations on the topics of trauma of abandonment, humiliation and injustice, and in creating an interconnected conglomerate of traumatic experience. Therefore, the emergence in the cognitive sphere of demobilized at least one cognitive representation of traumatic experience in one of these traumas may actualize the entire structure of traumatic experience at the cognitive level. Demobilized men without PPD have no analogue of the above cognitive formation. Gr. 2 reveals a link between cognitive representations on the topics of trauma of humiliation and injustice.
Since the severity of these infantile traumas among demobilized without PPD is insignificant, it is possible that the formation of cognitive representations of traumatic experience is not infantile but actual in nature. For a more detailed study for the peculiarities of the structure in cognitive representations of traumatic experience, 19 demobilized were selected, which revealed the highest rates for all representations (3-4 points). For them, the mean of the severity in the three injuries mentioned above was calculated, namely: abandonment - 23.42; humiliation - 23, 21; injustice - 25.43. These figures were lower than the similar figure for all Gr. 2. For those 19 demobilized, structural features of cognitive representations of traumatic experience were identified. The results are presented in Table 4.

Table 4.

Structural features for cognitive representations of traumatic experience among demobilized without PPD with high rates of representation

\begin{tabular}{|c|c|c|c|}
\hline Representations by traumas & Abandonment & Humiliation & Injustice \\
\hline Abandonment & $1,00^{* *}$ & $0,15^{*}$ & $0,14^{*}$ \\
\hline Humiliation & $0,15^{*}$ & $1,00^{* *}$ & $0,23^{* *}$ \\
\hline Injustice & $0,14^{*}$ & $0,23^{* *}$ & $1,00^{* *}$ \\
\hline
\end{tabular}

Note: top of the table - results for Gr. 1 ; bottom of the table - results for Gr. $2 ;^{*}-\mathrm{p} \leq 0,05 ; * *-p \leq 0,01$. 
The results presented in Table 4 prove that demobilized without PPD with high levels of cognitive representations have similar "sticking together" to that found among demobilized without PPD. As the indicators for the severity of infantile injuries of abandonment, humiliation and injustice are insignificant; we can assume that these are cognitive representations, reinforced by the influence of current experience. Therefore, the severity of cognitive representations on the topics of abandonment trauma, humiliation and injustice in the interaction of which revealed the phenomenon of "wrecking", do not contribute to the occurrence of PPD, unless potentiated by appropriate infantile traumatization.

\section{Conclusion}

1. Demobilized combatants with PPD show an intensity of all cognitive representations in traumatic experiences that are substantially closer to the topics of abandonment, humiliation and injustice, at a significantly higher level than those of demobilized non-PPDs. Therefore, current traumatic experiences reflect relevant childhood traumas that are filled with new meaningful content but generally correspond to infantile traumas.

2. In demobilized PPDs, the peculiarities in the structure for cognitive representations of traumatic experience consist of the "sticking together" and potentiation of representations on the topics of trauma of abandonment, humiliation and injustice and in the formation of an interconnected conglomerate of traumatic experience.

3. Expressiveness of cognitive representations on the topics of trauma of abandonment, humiliation and injustice in the interaction of which there is a phenomenon of "sticking together" (among demobilized without PPD), do not predispose to occurrence of PPD, unless potentiated by appropriate infantile traumatization.

\section{REFERENCES}

Kharchenko A.O. (2017). Особливості психотерапевтичної роботи 3 травматичним емоційним досвідом комбатантів [Peculiarities of psychotherapeutic work with traumatic emotional experience of combatants]. Psychological Counseling and Psychotherapy. 1(8), 67-73. https://doi.org/10.26565/2410-1249-2017-8-02.

Lauterbach V. (1995). The effectiveness of psychotherapy: criteria and results of evaluation. Psychotherapy: From theory to practice. Proceedings of the 1st Congress of the Russian Psychotherapy Association. - St.-Petersburg, ed. Psychoneurological Institute. Bekhtereva, 28-41.

Kocharyan A.S. (2014). Experience as a target of clientcentered psychotherapy. Psychological Counseling and Psychotherapy, 1-2, 24-36.

Kokun O.M., Agayev N.A., Pishko I.O, Lozinska N.S. (2016). Peculiarities of detection of PTSD diagnostic indicators in military personnel due to the influence of extreme factors of combat activity. Problems of extreme and crisis psychology. Collection of scientific works. 20. Kharkiv: NUZUU, 84 - 93.

Kozyra P.V., (2016). Феноменология психологической дезадаптации у сотрудников мвд украиныучастников в ATO [Phenomenology of psychological maladaptation among employees of the Ministry of Internal Affairs of Ukraine participating in the ATO], American Scientific Journal. 8. 40-46.

Kozyra P.V., (2016). Феноменология психологической дезадаптации у сотрудников мвд украиныучастников в ATO [Phenomenology of psychological maladaptation among employees of the Ministry of Internal Affairs of Ukraine participating in the ATO], American Scientific Journal, 8.

Методичні рекомендації. Психолого-психіатрична допомога постраждалим у збройних конфліктах [Guidelines. Psycho-psychiatric assistance to victims of armed conflict]. (2014). Kyyiv: Akademvydav, 34.

Tarabrina N.V., Agarkov V.A., Bykhovets Yu.V., Kalmykova E.S., Makarchuk A.V., Padun M.A., Udachina E.G., Himchan Z.G., Shatalova N.E., Shchepina A.I. (2007). A Practical Guide to the Psychology of Post-Traumatic Stress. Part 1. Theory and methods. Moscow: Publishing House "KogitoCenter", 143-148.

Workshop on the psychology of post-traumatic stress. (2001). St. Petersburg: Peter. 125-136.

\section{СТРУКТУРНІ ОСОБЛИВОСТІ КОГНІТИВНИХ УЯВЛЕНЬ ТРАВМАТИЧНОГО ЕМОЦІЙНОГО ДОСВІДУ СЕРЕД ДЕМОБІЛІЗОВАНИХ УЧАСНИКІВ БОЙОВИХ ДІЙ В УКРАЇНІ З ПОСТСТРЕСОВОЮ ПСИХОЛОГІЧНОЮ ДЕЗАДАПТАЦЕЮ}


резистентністю щодо терапевтичної роботи з ППД. Також описані (Срмошин А.Ф., Кочарян О.С.) деякі особливості травматичного досвіду особистості, а саме - травматичних переживань: їх соматизація, фрагментарність, циклічність та ін. Не достатньо розкритим залишається когнітивний компонент травматичного досвіду, що проявляється при ППД у військовослужбовців. Аналіз проблеми. Результати як теоретичних, так і практичних досліджень, в яких робилися спроби визначити особливості когнітивних репрезентацій травматичного досвіду військовослужбовців, мають фрагментарний характер. Концепція «емоційної сфери», запропонована Єліоттом Р. та Грінбергом Л., включає в себе когнітивну складову, як одну з базових частин травматичного досвіду особистості, що може бути використано для концептуалізації в дослідженні структури травматичного досвіду військовослужбовців. Мета дослідження - визначити структурні особливості когнітивних репрезентацій травматичного досвіду у військовослужбовців з ППД. Опис вибірки. Вибірка складається 3 двох груп. До першої увійшли чоловіки середнього віку, які пройшли службу в зоні АТО та були демобілізовані у кількості 100 чоловік. Друга група за вищезазначеними характеристиками ідентична, але це ті військовослужбовці, котрі мають показники за Міссісіпською шкалою, що відповідають вираженості ППД. Висновки. У демобілізованих учасників бойових дій з ППД виявлено вираженість за всіма когнітивними репрезентаціями травматичного досвіду, які є за змістом близькими до тематик покинутості, приниження та несправедливості, на суттєво більшому рівні, ніж у демобілізованих без ППД. вираженість когнітивних репрезентацій за тематиками травм покинутості, приниження та несправедливості у взаємодії яких виявлено феномен «злипання», не придеспонують до виникнення ППД, якщо не потенціюються відповідною інфантильною травматизацією.

КЛЮЧОВІ СЛОВА: військовослужбовці, постстрес, травматичний досвід, структура, когнітивні репрезентації.

\section{СТРУКТУРНЫЕ ОСОБЕННОСТИ КОГНИТИВНЫХ РЕПРЕЗЕНТАЦИЙ ТРАВМАТИЧЕСКОГО ЭМОЦИОНАЛЬНОГО ОПЫТА У ДЕМОБИЛИЗОВАННЫХ КОМБАТАНТОВ В УКРАИНЕ С ПОСТСТРЕССОВОЙ ПСИХОЛОГИЧЕСКОЙ ДЕЗАДАПТАЦИЕЙ}

Харченко А.А.

Факультет психологии, Харьковский национальный университет им. В.Н. Каразина Харьков, 61077, Украина

Постановка проблемы. В научной литературе существует определенная полипараметричность подходов касательно лечения ППД (постстрессовой психологической дезадаптации) у военнослужащих, что добавляет проблемности в работе с их жалобами и усложняется резистентностью касательно терапевтической работы с ППД. Также описаны (Ермошин А.Ф., Кочарян А.С.) некоторые особенности травматического опыта личности, а именно - травматических переживаний: их соматизация, фрагментарность, цикличность и др. Не достаточно раскрытым остается когнитивный компонент травматического опыта, который проявляется при ППД у военнослужащих. Анализ проблемьл. Результаты, как теоретических, так и практических исследований, в которых делались попытки определить особенности когнитивных репрезентаций травматического опыта военнослужащих, имеют фрагментарный характер. Концепция «эмоциональной сферы», предложенная Элиоттом Р. и Гринбергом Л. включает в себя когнитивную составляющую, как одну из базовых частей травматического опыта личности, что может быть использовано для концептуализации в исследовании структуры травматического опыта военнослужащих. Цель исследования: определить структурные особенности когнитивны репрезентаций травматического опыта у военнослужащих с ППД. Описание выборки. Выборка состоим из двух групп. В первую вошли мужчины среднего возраста, которые прошли службу в зоне АТО и были демобилизованы - 100 человек. Вторая группа за вышеуказанными характеристиками идентична, но это те военнослужащие, которые имеют показатели за Миссисипской шкалой, что соответствуют выраженности ППД. Выводы. У демобилизованных участников боевых действий с ППД определено выраженность за всеми когнитивными репрезентациями травматического опыта, которые по содержанию близки к тематикам брошенности, унижения, и несправедливости, на существенно большем уровне, чем у демобилизованных без ППД. Выраженность когнитивных репрезентаций за тематиками травм брошенности, унижения, и несправедливости во взаимодействии которых выявлен феномен «слипания», не придеспонирует к возникновению ППД, если не потенцируется соответствующей инфантильной травматизацией.

КЛЮЧЕВЫЕ СЛОВА: военнослужащие, постстресс, травматический опыт, структура, когнитивные репрезентации. 